Int. J. Dev. Biol. 60: 159-166 (2016)

doi: $10.1387 / \mathrm{ijdb} .160058 \mathrm{id}$

\title{
Genes regulated by potassium channel tetramerization domain containing 15 (Kctd15) in the developing neural crest
}

\author{
THOMAS C.B. WONG\#,1, MARTHA REBBERT"\#,2, CHENGDONG WANG ${ }^{1}$, XIONGFONG CHEN $^{3}$, \\ ALISON HEFFER ${ }^{2}$, VALERIA E. ZARELLI ${ }^{2}$, IGOR B. DAWID ${ }^{*, 2}$ and HUI ZHAO*,1,4 \\ ${ }^{1}$ School of Biomedical Sciences, Faculty of Medicine, The Chinese University of Hong Kong, Shatin, New Territories, \\ Hong Kong, P. R. China, ${ }^{2}$ Section of Developmental Biology, DDB, The Eunice Kennedy Shriver National Institute \\ of Child Health and Human Development, National Institutes of Health, Bethesda, MD, USA, ${ }^{3}$ Advanced Biomedical \\ Computing Center, National Cancer Institute, National Institutes of Health, Frederick, MD, USA and ${ }^{4}$ Kunming \\ Institute of Zoology Chinese Academy of Sciences-The Chinese University of Hong Kong Joint Laboratory of
} Bioresources and Molecular Research of Common Diseases

\begin{abstract}
Neural crest (NC) development is controlled precisely by a regulatory network with multiple signaling pathways and the involvement of many genes. The integration and coordination of these factors are still incompletely understood. Overexpression of Wnt3a and the BMP antagonist Chordin in animal cap cells from Xenopus blastulae induces a large number of NC specific genes. We previously suggested that Potassium Channel Tetramerization Domain containing 15 (Kctd15) regulates NC formation by affecting Wnt signaling and the activity of transcription factor AP-2. In order to advance understanding of the function of Kctd15 during NC development, we performed DNA microarray assays in explants injected with Wnt3a and Chordin, and identified genes that are affected by Kctd15 overexpression. Among the many genes identified, we chose Duf domain containing protein 1 (ddcp 1), Platelet-Derived Growth Factor Receptor a (pdgfra), Complement factor properdin (cfp), Zinc Finger SWIM-Type Containing 5 (zswim5), and complement component 3 (C3) to examine their expression by whole mount in situ hybridization. Our work points to a possible role for Kctd15 in the regulation of NC formation and other steps in embryonic development.
\end{abstract}

KEY WORDS: Neural crest, Kctd15, DNA microarray, Xenopus, gene regulation, transcription factor AP-2

The Kctd family of proteins has received increasing attention due to its multiple biological functions and putative roles in human disease. The family is composed of over 20 genes/proteins in different vertebrate species and can be subdivided into seven subgroups on the basis of sequence similarity (Liu et al., 2013, Skoblov et al., 2013). A number of Kctd genes have been associated with human diseases, as summarized by Liu and colleagues (Liu et al., 2013). All members of the family share a Bric-a-brack, Tram-track, Broad complex (BTB) domain usually located in the $\mathrm{N}$-terminal half of the protein. BTB domains, also called POZ domains, are widely involved in protein-protein interactions (Perez-Torrado et al., 2006, Stogios et al., 2005), and thus it is not surprising that acting as adapters is perhaps the best-studied molecular function of Kctd proteins. Kctd5, Kctd 6 and Kctd 11 bind Cullin 3 and act as adapters mediating the interactions of E3 ubiquitin ligases with their substrates (Balasco et al., 2014, Bayon et al., 2008, Canettieri et al., 2010, Chen et al., 2009, Correale et al., 2011). While other Kctd proteins also have been reported to bind Cullin 3 , this has been contradicted in recent work (Smaldone et al., 2015). Kctd8, Kctd12 and Kctd16 associate with GABA receptors, modulating their activity (Rajalu et al., 2015); these genes also show striking left/right asymmetry in their expression in the brain (Gamse et al., 2005). Other family members appear to have very different molecular functions by acting in the regulation of transcription. These include Kctd10, a

Abbreviations used in this paper: AC, animal cap; $\mathrm{C}$, complement component; cfp, complement factor properdin; ddcp, Duf domain containing protein; Kctd, potassium channel tetramerization domain containing; NC, neural crest; NPB, neural plate border; pdgfra, platelet-derived growth factor receptor a; zswim, zinc finger SWIM-type containing.

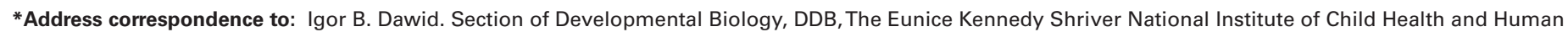

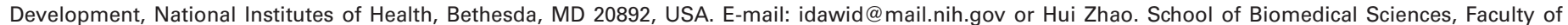

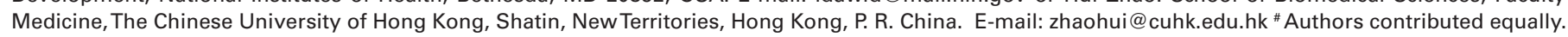

Supplementary Material (five tables) for this paper is available at: http://dx.doi.org/10.1387/ijdb.160058id

Accepted: 6 April 2016.

ISSN: Online 1696-3547, Print 0214-6282 
factor involved in heart development through the inhibition of Tbx5a activity, apparently by direct interaction between the Tbx and Kctd components (Hu et al., 2014, Tong et al., 2014). In addition Kctd10 also interacts with proliferating cell nuclear antigen and through this interaction affects proliferation (Wang et al., 2009).

We have been interested in the functions of Kctd15 in Xenopus and zebrafish development. We found that overexpression of Kctd15 leads to very effective inhibition of the formation of the neural crest (NC), suggesting the possibility that Kctd15 regulates the size of the NC domain in development (Dutta and Dawid, 2010, Groves and LaBonne, 2014). Kctd 15 and the closely similar Kctd1 have two distinct molecular functions, inhibition of canonical Wnt signaling (Dutta and Dawid, 2010, Li et al., 2014) and inhibition of the function of transcription factor AP-2 (Ding et al., 2009, Zarelli and Dawid, 2013). Both of these functions may be responsible for the suppression of NC formation by Kctd 15 as Wnt signaling and AP-2 activity are essential for NC induction and differentiation (Brewer et al., 2004, de Croze et al., 2011, Ikeya et al., 1997, Knight et al., 2005, Li and Cornell, 2007, Luo et al., 2003, Luo et al., 2005, Saint-Jeannet et al., 1997, Schorle et al., 1996, Simoes-Costa and Bronner, 2015). Based primarily on the strength of the inhibitory effect we believe that Kctd15 suppression of AP-2 activity may be the dominant mechanism in its blocking of NC development. Mutations in KCTD1 in humans are responsible for scalp-ear-nipple (SEN) syndrome (Marneros et al., 2013), but it is not known whether inhibition of AP-2 or Wnt signaling plays a role in the etiology of this disease. KCTD15 has not been reported as the cause of a disease, but numerous studies show an association between this gene and obesity (Gutierrez-Aguilar et al., 2012, Leon-Mimila et al., 2013, Mei et al., 2012, Willer et al., 2009, Williams et al., 2012). It is known that AP- $2 \alpha$ regulates the activity of $\mathrm{C} / \mathrm{EBP} \alpha$ during adipogenesis (Jiang et al., 1998), and AP-2 $\beta$ affects other steps of adipogenesis and insulin resistance (Ikeda et al., 2006, Meng et al., 2010, Tao et al., 2006, Zhang et al., 2014). It is tempting to speculate that the association of KCTD15 with obesity is based on its ability to inhibit AP-2 proteins, but evidence for this hypothesis in vertebrates is not available to date.

Beyond NC development and adipogenesis, the two pathways affected by Kctd15, Wnt signaling and AP-2 transcriptional regulation, have wide-ranging roles in development, physiology and disease (http://web.stanford.edu/group/nusselab/cgi-bin/wnt/) (Eckert et al., 2005, Hilger-Eversheim et al., 2000, Hoffman etal., 2007, Orso etal., 2008, Wenke and Bosserhoff, 2010). The role of Kctd15 in different tissues and cell types and the global role of Kctd15 in development have not been studied so far. We investigated Kctd15 function broadly through transcriptome analysis by DNA microarray. As test tissue we chose Xenopus laevis animal explants (animal caps) that were injected with Wnt and Chordin (Chd) mRNAs, which induce the expression of NC marker genes (Saint-Jeannet et al., 1997). Recently the transcriptome of animal caps overexpressing Pax3 and Zic1 has been analyzed (Bae et al., 2014, Plouhinec et al., 2014).
A

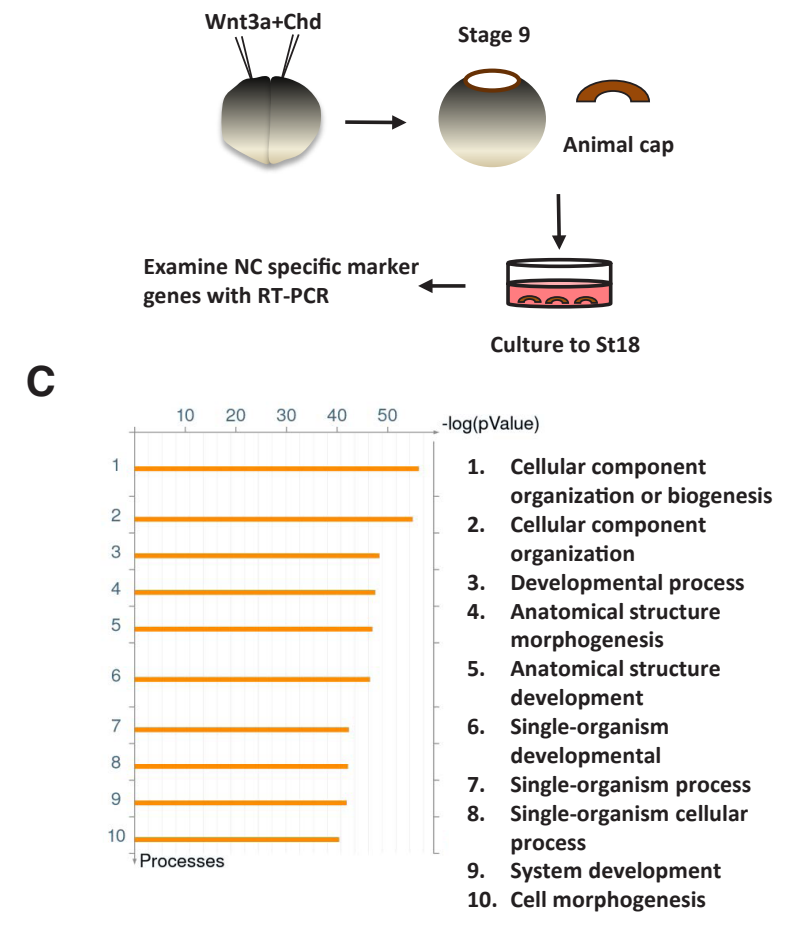

GO analysis of Wnt+Chd vs Lac Z

B

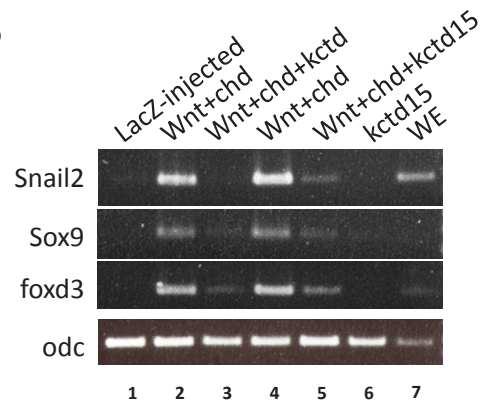

D

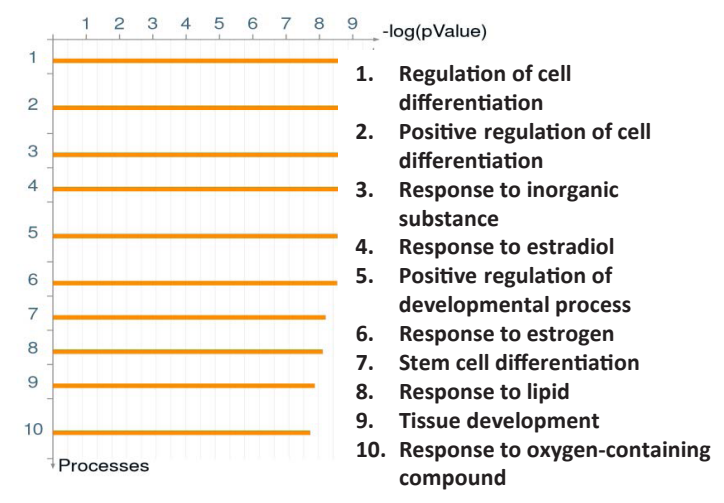

GO analysis of Wnt+chd+kctd15 vs wnt+chd

Fig. 1. Transcriptome analysis of animal explants induced by co-injection of wnt3a and chd mRNA. (A) Schematic diagram of experimental procedures. (B) Kctd15 suppressed the expression of NC marker genes in animal cap assays. Both blastomeres of two-cell stage embryos were injected with the indicated mRNAs. RT-PCR was performed to examine expression of snai2, sox9, and foxd3. Co-overexpression of wnt3a and chd strongly induced the expression of these genes, and the induction was suppressed by addition of kctd15. Odc was the loading control. WE, whole embryos. $(\mathbf{C}, \mathbf{D})$ The top ten enriched GO terms in differentially expressed genes in the comparison of $(B)$ induced to control (WC/L), and (C) induced/inhibited to induced (WCKMC) animal caps. 
This procedure is more selective for NC induction (Hong and SaintJeannet, 2007, Milet et al., 2013), but we chose Wnt/Chd injection to test broadly for effects of Kctd 15 at the neural plate border (NPB). Among genes induced by Wnt/Chd and inhibited by Kctd15 we find many well characterized NC markers as well as several hatching gland markers. We further identify several strongly affected genes not previously studied in this context whose further analysis may contribute to an understanding of the role of Kctd15 and AP-2 in NC formation and other processes in the embryo.

\section{Results}

\section{Identification of genes regulated by Kctd15 during neural crest formation}

We wished to survey the range of genes that are inhibited by Kctd15 overexpression in the context of NC induction by using Affymetrix DNA microarray. Injection of RNA encoding a Wnt and a BMP inhibitor such as Chordin into Xenopus embryos followed by animal cap culture (Fig. 1A) leads to the induction of many NC and additional NPB border genes (Saint-Jeannet et al., 1997), whereas co-injection of Kctd15 inhibits induction (Dutta and Dawid, 2010). Recent analyses by other workers have focused on induction of NC genes more selectively by Pax3 and Zic1 (Bae et al., 2014, Plouhinec et al., 2014). We injected four sets of RNAs, lacZ as control (L), wnt3a+chd (WC), wnt3a+chd+kctd15 (WCK), and kctd15 (K). We tested several NC markers by PCR and found that, as predicted, wnt+chd induced, and kctd15 inhibited NC marker expression (Fig. 1B). Microarray analysis was then carried out (for raw data see GEO accession number GSE72391). Here we will deal with the two relevant comparisons: WC vs. L, representing genes activated during NPB/NC induction, although additional genes are affected; and WCK vs. WC, representing genes inhibited by Kctd 15 in the context of $\mathrm{Wnt} / \mathrm{Chd}$ overexpression. For further analysis we selected genes with a fold change of two or greater and a $p$ value $<0.05$. Under the criteria stated above, there are 2869 Affymetrix probe sets that are induced by Wnt/Chd, while 3680 probe sets are suppressed (Supplementary Table S2). Note that Affymetrix probe sets often represent genes repetitively; nevertheless we will use "genes" to stand for "probe set" hereafter. A number of known NPB or NC genes were strongly induced by Wnt/Chd overexpression (Table 1), supporting the microarray results.

Gene ontology (GO) analysis of the NPB/NC transcriptome revealed that GO terms of cellular component organization or biogenesis, cellular component organization, developmental process, anatomical structure morphogenesis, anatomical structure development, single-organism developmental process, single-organism process, single-organism cellular process, system development, and cell morphogenesis are highly represented (Fig. 1C).

We next surveyed the comparison of WCK vs. WC, and found that 334 genes are suppressed by addition of Kctd15, while 210 genes were increased under the criteria stated above (Supplementary Table S3). Among the suppressed genes we found all genes listed in Table 1 except pax3a/b and zic1 (see Discussion). Expression of Kctd15 itself was much reduced in WCKanimal caps, suggesting that Kctd 15 negatively regulates its own expression. Gene ontology analysis showed that GO terms regulation of cell differentiation, positive regulation of cell differentiation, response to inorganic substance, response
TABLE 1

\section{INDUCTION AND REPRESSION BY KCTD15 OF KNOWN GENES CHARACTERISTIC FOR NEURAL BORDER AND NEURAL CREST}

\begin{tabular}{|c|c|c|c|c|c|}
\hline Gene & Unigene & WC vs $L$, Fold & WC vs $L, p$ & WCK vs WC, Fold & WCK vs WC, $p$ \\
\hline foxd3a $a^{+\#}$ & XI.525 & 144 & $1.22 \mathrm{E}-05$ & -5.23 & 0.013 \\
\hline pax3b" & XI.45266 & 129 & $9.44 \mathrm{E}-05$ & N. S. & \\
\hline foxd $3 b^{+\#}$ & $\mathrm{XI} .523$ & 119.3 & 3.93E-05 & -5.65 & 0.018 \\
\hline zic1" & Xl.1796 & 105.3 & 4.44E-05 & N. S. & \\
\hline рах3а" & $X I .49495$ & 84.86 & 3.71E-04 & N. S. & \\
\hline $\operatorname{sox} 9 a^{+\#}$ & XI.1690 & 51.5 & 8.00E-05 & -14.13 & 0.0011 \\
\hline $\operatorname{Im} \times 1 b .1^{+\#}$ & XI.12464 & 38.52 & 4.39E-06 & -2.57 & 0.0013 \\
\hline $\operatorname{sox} 10^{\#}$ & XI.1588 & 36.2 & 0.00359 & -12.56 & 0.02 \\
\hline $\operatorname{sox} 8^{+}$ & $X I .29789$ & 34.28 & 2.34E-05 & -5.4 & 0.0011 \\
\hline snail2a ${ }^{+\#}$ & XL.3818 & 26.6 & 0.0009033 & -20.54 & 0.0015 \\
\hline twist $1 b^{+\#}$ & $X I .56708$ & 10.8 & $6.86 \mathrm{E}-05$ & -3.21 & 0.0061 \\
\hline tfap2e $e^{\#}$ & XI.50785 & 4.427 & 0.000404 & -2.2 & 0.016 \\
\hline
\end{tabular}

WC, Wnt+Chd, referring to RNA from animal caps injected with these mRNAs; L, LacZ; WCK, Wnt+Chd+Kctd15. N.S., change not significant.

+ Genes identified in Table 2 or Table 3 of (Bae et al., 2014).

\# Genes identified in Table 2 or Table S1 of (Plouhinec et al., 2014).

\section{TABLE 2}

\section{MICROARRAY VALUES FOR INDUCTION AND INHIBITION OF GENES TESTED BY IN SITU HYBRIDIZATION}

\begin{tabular}{lccccc} 
Gene & Unigene & WC vs L, Fold & WC vs L, p & WCK vs WC, Fold & WCK vs WC, p \\
\hline ddcp1 & XI2.13675 & 27.0745 & $3.54 \mathrm{E}-06$ & -4.09502 & 0.00135358 \\
pdgfra & $\mathrm{XI} 2.20029$ & 16.6366 & $2.33 \mathrm{E}-05$ & -3.5796 & 0.00230006 \\
cfp & $\mathrm{XI} 2.41202$ & 8.49842 & $4.00 \mathrm{E}-06$ & -2.36589 & 0.00214363 \\
zswim5 & $\mathrm{XI} 2.40416$ & 3.04663 & 0.0003077 & -2.40434 & 0.00142697 \\
c3 & $\mathrm{XI} 2.44891$ & 14.404 & 0.0166839 & -6.64701 & 0.0951221 \\
\hline
\end{tabular}

See Table 1 for abbreviations.

to estradiol, positive regulation of developmental process, response to estrogen, stem cell differentiation, response to lipid, tissue development, response to oxygen-containing compound are significantly enriched (Fig. 1D). While multiple terms are included, Kctd15 appears to affect most strongly aspects of cell differentiation.

\section{ddcp1}
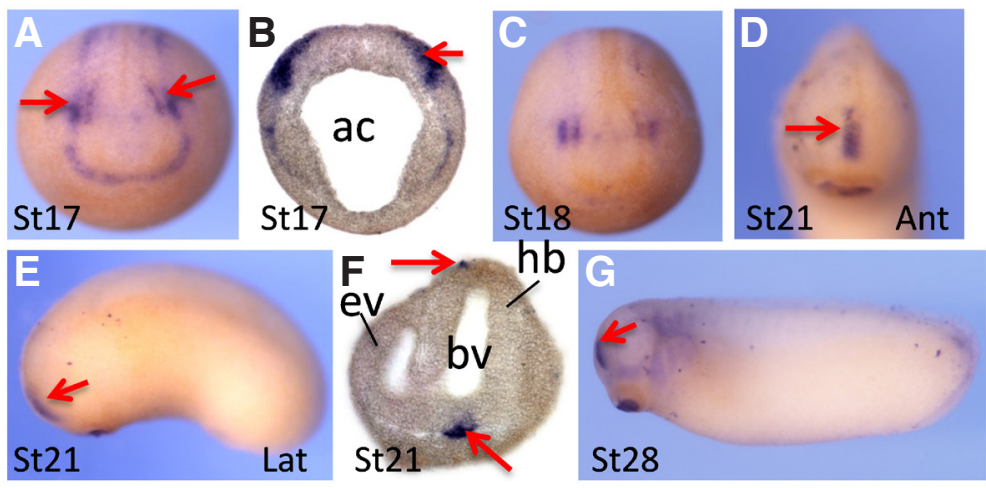

Fig. 2. Spatial expression pattern of ddcp1 encoding a Duf domain protein. (A-C) ddcp1 was expressed along the edge of neural plate. Notably, two stronger staining patches (arrows) were detected in whole mount embryos (A) and transverse sections (B). With the closure of neural tube, the two signaling patches merged and were located at the frontal region of the head (D-G). Ant, anterior view; lat, lateral view. Ac, archerteron; ev, eye vesicle; bv, brain vesicle; $h b$, hindbrain. 

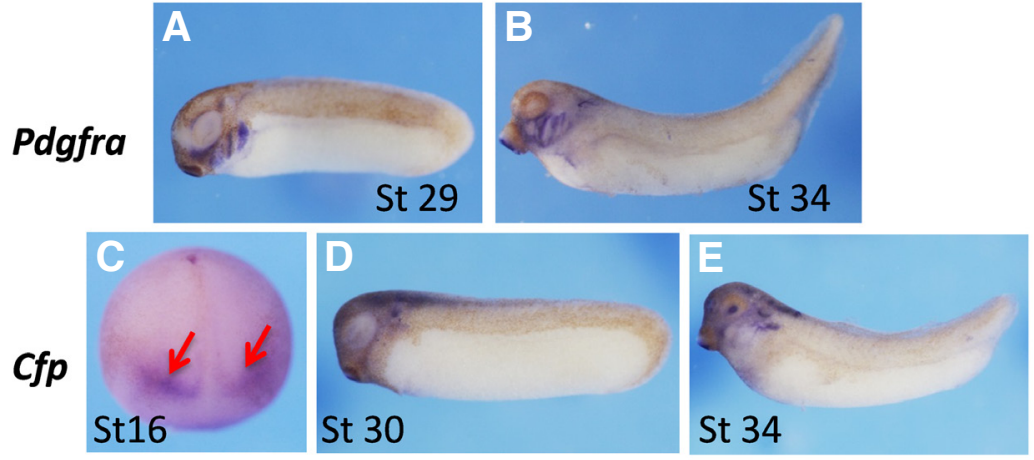

Fig. 3. Spatial expression pattern of pdgfra and cfp. (A-B) Strong signals of pdgfra were detected in branchial arches at tail bud and tadpole stages. (C-E) Cfp signals were detected first at mid neurula stage, and appear as two stripes at the anterior neural plate indicated by red arrows (C). The signals were detected in brain, lens, and ear vesicle at tail bud and tadpole stages (D, E).

As two recent reports examined gene expression in ACs induced to form NC by pax3 and zic1 injection (Bae et al., 2014, Plouhinec et al., 2014), we tested the overlap between the gene sets in GEO submissions associated with these references and our data, using genes changed by 2 -fold or more in either direction at $p<0.05$. Among 203 genes increased in the data of Plouhinec et al., 154 are also increased in our data, and among 227 decreased genes, 205 in our set are likewise decreased (Supplementary Table S4).

\section{Zswim 5}
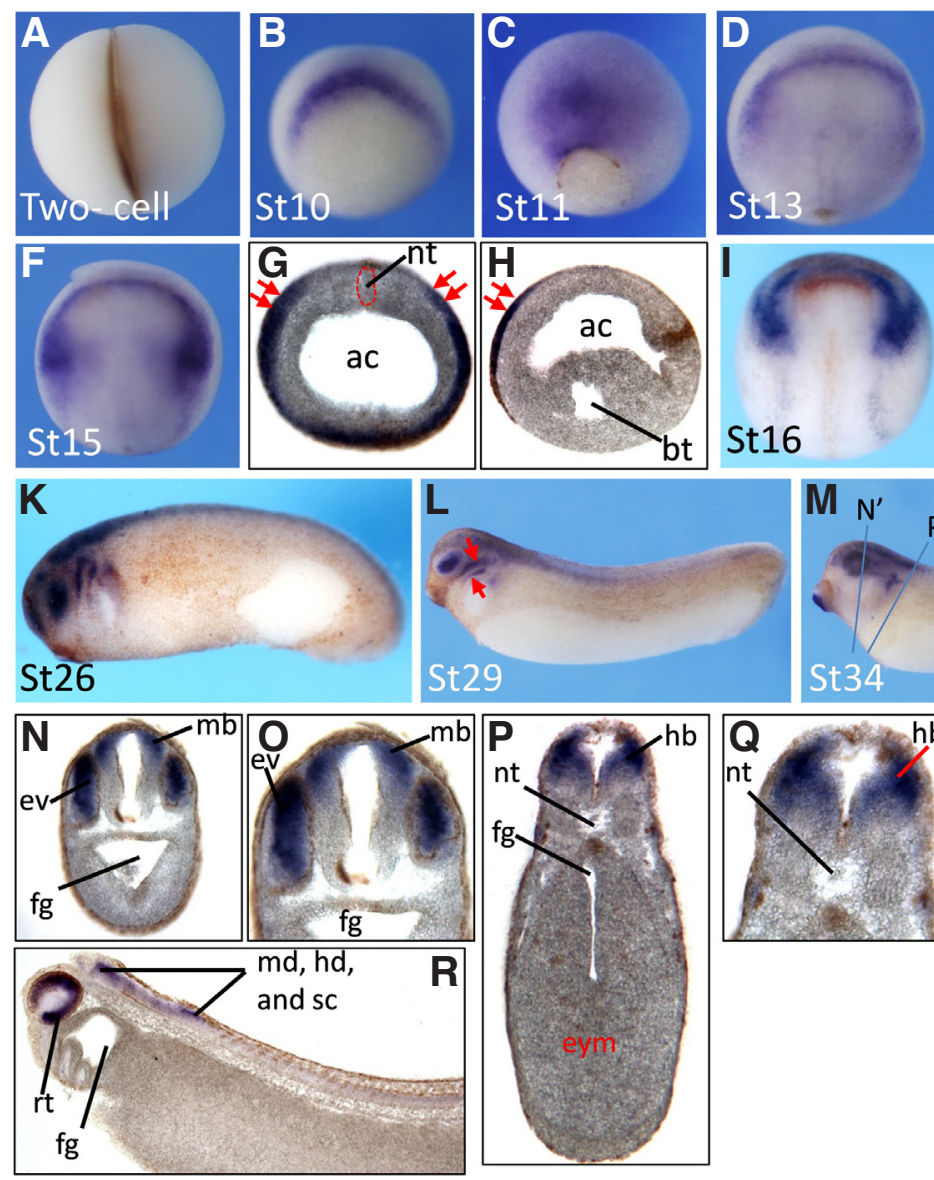
St34

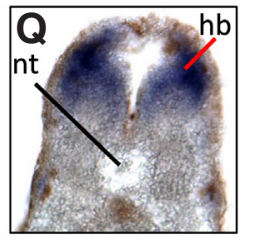

In the comparison with the work of Bae et al., of 713 increased genes 702 are also increased in our data, and among 863 decreased genes 853 are decreased in our data (Supplementary Table S5). Thus the overlap with both sets of data is high.

\section{Developmental expression of selected genes affected by Kctd15}

We next used whole mount in situ hybridization to examine the expression pattern of genes encoding Duf domain protein 1 (ddcp 1), Platelet-derived growth factor receptor a (pdgfra), Complement factor properdin (cfp), Zinc finger SWIM-Type Containing 5 (zswim 5), and Complement component $C 3$ (Table 2).

Duf domain containing protein 1(ddcp1) encodes a protein that has not been characterized, and even the function of the Duf domain is unknown. Signals for $d d c p 1$ became visible at neurula stages, forming stripes along the anterior and lateral edges of neural fold (Fig $2 \mathrm{~A}, \mathrm{~B})$. Two signal patches at each side with higher intensity can be observed at the future head region (arrows in Fig. 2A). Transverse sections at stage 18 indicated that staining was localized in a region extending from ectoderm, mesoderm to the endoderm (Fig. 2B). With the progress of neural fold closure, the two signal patches seem to merge and form a short strip at the midline of the head region at tadpole and tailbud stages (Fig. 2C-E,G). Transverse sections identify an additional expression region of $d d c p 1$ at the stomodeal-hypophyseal anlage (Fig. 2F).

Platelet-derived growth factor receptor
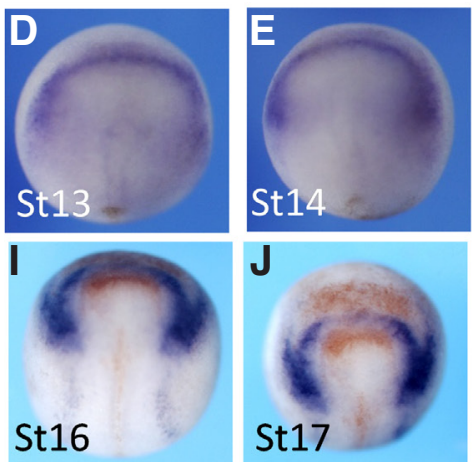
(Pdgfr) is a receptor tyrosine kinase that has been identified as a pax3/zic1 target (Bae et al., 2014, Plouhinec et al., 2014). These authors also showed expression of pdgfra in the NC region at neurula stages. We found strong expression in the branchial arches in tail bud and tadpole stage embryos (Fig. $3 \mathrm{~A}, \mathrm{~B}$ ).

Complement factor properdin (Cfp) is a cytoplasmic glycoprotein that is implicated in regulating the alternative complement pathway of the innate immune system (Ali et al., 2014). Cfp transcripts can be detected in neurula

Fig. 4. Spatial expression pattern of zswim5. Zswim5 was first detected at the dorsal blastopore lip in early gastrula $(\mathbf{A}, \mathbf{B})$, and then was preferentially expressed in the future neural plate at later gastrula stages (C). At early neurula stages, zswim5

signals were restricted at the anterior neural plate, partially covering the NC region (D-F). (G,H) Transverse section $(\mathbf{G})$ and sagittal section (H) of stage 15 embryos. Red arrows point to stained regions. At mid neurula stages, zswim5 signals were restricted in NC and anterior border of the neural plate (I,J). (K-R) Zswim5 expression at tail bud and tadpole stages. Zswim5 was mainly expressed in the anterior neural tube including forebrain, midbrain, hindbrain, and anterior portion of the spinal cord. In addition, signals were also detected in the retina of the developing eye and the forming cranial nerves (pointed by red arrows). $N^{\prime}$ and $P^{\prime}$ indicate the planes of the sections shown in $N$ and $P$, respectively. Ac, archenteron; bt, blastocoel; ev, eye vesicle; eym, endodermal yolk mass; fg, foregut; hb, hindbrain; mb, midbrain; $n t$, notochord; rt, retina; and sc, spinal cord. 


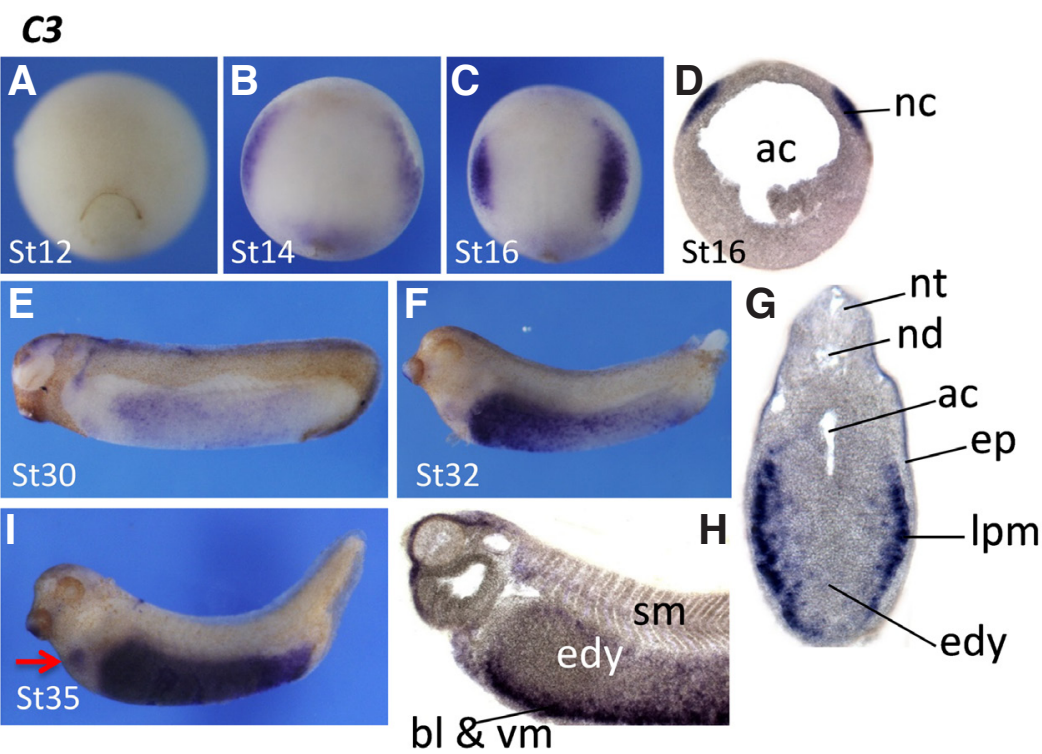

Fig. 5. Spatial expression pattern of complement component C3 (C3). C3 signals were not detected by late gastrula stages (A). Its expression appeared at the anterior border of the neural plate, and then became restricted at the NC (B, C). NC expression was confirmed by sectioning (D). C3 expression in the NC declined quickly, and an expression domain gradually appeared at the ventral region of the trunk $(\mathbf{E}, \mathbf{F})$. Sections from stage 32 embryos indicated that C3 was expressed in the somatic and splanchnic layer of lateral plate mesoderm just internal to the epidermis. (G), sagittal section; (H), transversal section. Endodermal expression is prominent at later stages (I). Arrow points to an expression domain in the heart primordium. Ac, archenteron; bl, blood island; edy, endodermal yolk mass; ep, epidermis; Ipm, lateral plate mesoderm; $n c$, neural crest; nt, neural tube; nd, notochord; sm, somite; vm, ventral mesoderm.
C3 was specifically observed in the NC at stage 16 , and this expression was confirmed by sectioning (Fig. 5C,D). At the tail bud and tadpole stages, a strong $C 3$ signal was observed in the trunk region, whereas the head was much less stained. Transverse sections of embryos after whole mount in situ hybridization revealed that the $C 3$ transcripts are located in a region corresponding to the somatic and splanchnic layer of lateral plate mesoderm, and ventral mesoderm including the blood island (Fig. $5 \mathrm{E}-\mathrm{H})$. At stage 35, C3 stains the heart primordium in addition to intense endodermal expression (Fig. 5I). C3 expression in Xenopus has previously been reported by McLin and colleagues (McLin et al., 2008). While there are some differences in detail our results confirm strong NC expression at stage 16-17, and strong endodermal expression at later stages.

To validate the microarray data, we examined the expression of zswim5 and $C 3$ upon overexpression of $k c t d 15$ by in situ hybridization. We injected $k c t d 15$ mRNA into either both blastomeres of two-cell stage embryos or two dorsal blastomeres of four-cell stage embryos, and checked the expression of zswim5 and C3. Overexpression of kctd15 dramatically reduced zswim5 and C3 staining, consistent with our microarray data (Fig. 6; Table 2).

\section{Discussion}

Further exploration of the regulatory network that controls NC formation is essential for understanding this developmental process in the normal embryo and the stage embryos, presenting as two diffuse stripes extending laterally from the dorsal midline of stage 16 embryos. Expression of $c f p$ was observed in the neural tube, otic vesicle, and dorsal region of the branchial arches at tadpole stages (Fig. 3 D,E).

Zinc Finger SWIM-Type Containing 5 (zswim5) encodes a protein that remains to be characterized. Whole mount in situ hybridization indicates that zswim5 was not expressed before gastrula stages (Fig. 4A). Staining was first detected in the dorsal blastopore lip at the onset of gastrulation (Fig. 4B). The positive region expanded and covered the prospective neural plate at mid gastrula stage (Fig. 4C). At the early neurula stages, zswim5 was expressed at the anterior border of the neural plate, partially overlapping with the $\mathrm{NC}$ region (Fig. $4 \mathrm{D}-\mathrm{F}$ ), and this expression was further confirmed by transverse and sagittal sections (Fig. 4G,H). Weak signals were also detected along the lateral border of the neural plate, extending posteriorly. At mid and late neurula stages, zswim5 was detected in the anterior border of the neural plate and the NC (Fig. 4 I,J). At tail bud and tadpole stages, zswim5 expression can be detected in the brain and anterior portion of spinal cord. In addition, it was also detected in the eye, especially in the retina region (Fig. $4 \mathrm{~K}-\mathrm{R}$ ). It is notable that some regions of forming cranial nerves were also stained (pointed by arrow in Fig. 4L) (Wang et al., 2011).

Complement component 3 (C3) is one of the key components in activation of the complement system in higher vertebrates. Its activation is required for both classical and alternative complement activation pathways. $C 3$ transcripts became visible from the early neurula stages onward (Fig. 5 A,B). At stage 14, the $C 3$ transcripts were detected at the edge of the forming neural plate. Staining for pathological conditions due to disturbed NC development. Kctd15 was previously implicated in the regulation of NC formation, as overexpression of Kctd15 causes strong inhibition of NC development (Dutta and Dawid, 2010). In order to further understand the molecular events regulated by Kctd15, we performed DNA microarray analysis to identify genes that are affected by Kctd15

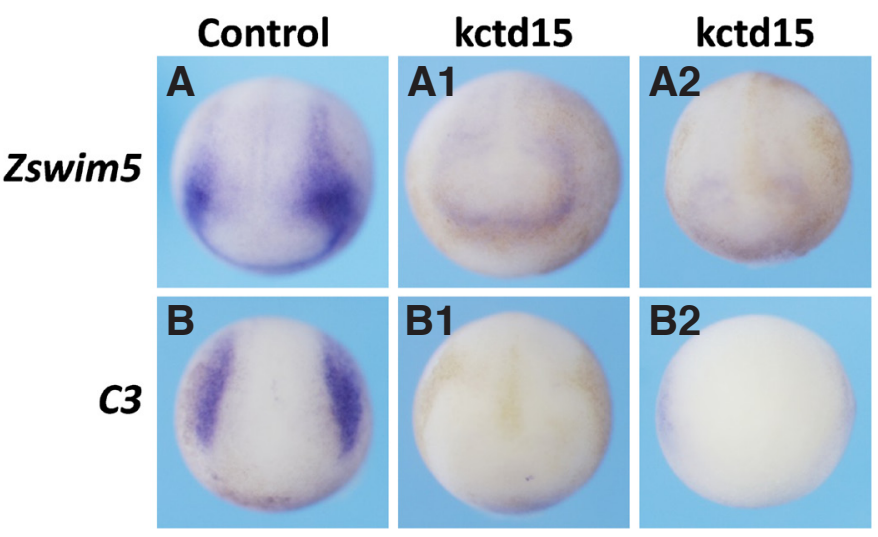

Fig. 6. Overexpression of Kctd15 inhibits expression of zswim5 and C3.

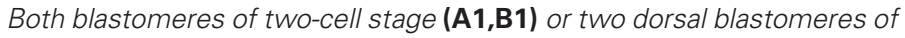
four-cell stage embryos (A2,B2) were injected with $\mathrm{kctd} 15 \mathrm{mRNA}$, and the injected embryos were collected at about stage 16. The expression zswim5 and $\mathrm{C} 3$ was strongly inhibited compared to those in control embryos (A,B). (A1) $72 \%, 13$ of 18 embryos; (A2), 95\%, 19 of 20 embryos; (B1), 58\%, 11 of 17 embryos, and (B2) 73.7\%, 14 of 19 embryos. 
during NC formation.

In the system we used, Xenopus animal caps induced by inhibition of BMP and activation of Wnt signaling, NC differentiation is elicited together with other events. Yet this system allows a broad evaluation of genes that are affected during the induction process. We found activation of expression of multiple genes known to be characteristic of NC development, some of which are illustrated in Table 1. In line with previous findings, we also detected components involved in modulating Wnt (Shisa), retinoic acid (rarres1, cyp26c1, cyp26a1), and BMP (bambi) signaling, and other genes identified in earlier work. In addition, we have identified a number of novel genes that are induced under these conditions and future analysis will be needed to elucidate their possible functions in NC specification and differentiation.

During the NC specification, coordination of pax3 and zic1gene activity is essential and sufficient to initiate this complex process (Bae et al., 2014, Garnett et al., 2012, Hong and Saint-Jeannet, 2007, Milet et al., 2013, Monsoro-Burq et al., 2005, Sato et al., 2005). Two recent papers reported the target gene profile of Pax3 and Zic1, both of which utilized inducible constructs in order to identify genes specifically involved in NC specification, EMT induction, and migration. Comparison of our results with those of (Bae et al., 2014) and (Plouhinec et al., 2014) shows a considerable degree of overlap (see Results).

The focus of our study has been to identify genes whose activation during manipulation of Wnt and BMP signaling is sensitive to Kctd15. In the subset of genes shown in Table 1, all except pax3a/b and zic1 are strongly inhibited. As Kctd15 strongly inhibits AP-2 function in addition to lesser inhibition of Wnt signaling (Dutta and Dawid, 2010, Zarelli and Dawid, 2013), these results suggest that pax3 and zic1 expression in the neural border might be independent of AP-2. Using morpholino-mediated knock-down and enhancer studies, de Croze et al., (de Croze et al., 2011) found that expression of pax3, but not of zic1 depends on AP-2 function in this system. A possible explanation for this difference may be that different members of the AP-2 family may be involved with different Kctd15 sensitivity, or that the particular pax3 enhancer studied confers Kctd15 resistance on AP-2 molecules bound to it. In any case, it is of interest that Kctd15 can inhibit expression of multiple genes lower in the NC induction hierarchy, but does not affect two genes at its top.

Members of sox gene family, notably sox8, sox9 and sox10, are strongly activated by NC induction and are very susceptible to overexpression of kctd15. All three genes belong to the soxE group, which are known to be important to NC formation (Haldin and LaBonne, 2010). The effect of Kctd15 on soxE gene expression is likely through inhibition of AP-2 function, known to be upstream of the sox genes in NC formation (de Croze et al., 2011). In addition, Kctd15 may have a role in chondrogenesis and osteogenesis as Sox 9 and Sox10 are essential in these two developmental processes (Kozhemyakina et al., 2015, Long and Ornitz, 2013). Some matrix metallopeptidases including adam33, mmp3 and mmp28a, and the genes involved in ER stress and the secretory pathway such as creb3l2 and dnajb9 are also inhibited by ectopic Kctd15 (Supplementary Table S3), suggesting again a broad spectrum of developmental processes that can be regulated by Kctd15.

We have examined the expression of some genes induced by Wnt/Chd and repressed by Kctd15, i.e. ddcp1, pdgfra, cfp, zsmim5 and $C 3$, by in situ hybridization, and further confirmed that zswim5 and $C 3$ are inhibited by overexpression of Kctd15. We chose these genes because their possible role in NC formation was not previously noted, or noted but not studied extensively. We find expression of these genes variously in the neural border, premigratory NC, subsequent NC derivatives, and also in unrelated tissues. These observations suggest that Kctd15 may affect the development of multiple cells and tissues in embryogenesis. The large number of genes affected by Kctd15 in our experiments further suggest that the molecular function of Kctd15 might be in the regulation of transcription rather than in other pathways as indicated for different members of the Kctd family (Balasco et al., 2014, Bayon et al., 2008, Canettieri et al., 2010, Chen et al., 2009, Correale et al., 2011). Our results provide a framework for future studies into the biological role of Kctd15.

\section{Materials and Methods}

\section{Embryo manipulation}

In vitro fertilization and $X$. laevis embryo culture were performed as described previously (Wang et al., 2011). Embryos were staged according to Nieuwkoop and Faber (Nieuwkoop and Faber, 1967). Experiments have been approved by the NICHD Animal Care and Use Committee. Capped mRNA for microinjection was prepared with mMessage mMachine kit (Invitrogen) and purified with RNeasy mini kit (Qiagen).

\section{Total RNA extraction}

Total RNA was extracted using the TRIzol reagent (Invitrogen) and precipitated by isopropanol. After DNase I treatment, the total RNA was purified with RNeasy purification kit (Qiagen).

\section{Animal cap assay and RT-PCR}

Animal cap assay was performed as described previously (Shi et al., 2015, Zhao et al., 2008). Briefly, animal caps were dissected from stage 9 embryos that had been injected with the indicated mRNAs, and were cultured till the sibling embryos reached stage 18. Total RNA was extracted for microarray or RT-PCR assays. cDNA was synthesized using Superscript III (Invitrogen) following the manufacturer's manual. Primers for RT-PCR are listed in Supplementary Table S1.

\section{Whole mount in situ hybridization}

The EST clones were purchased from GE Healthcare. The preparation of digoxigenin-labeled RNA probe and whole mount in situ hybridization were performed as described previously (Shi et al., 2015, Wang et al., 2015). Embryos probed with indicated antisense RNAs were sectioned by a vibratome (Zeiss) to a thickness of $50 \mu \mathrm{m}$ (Shi et al., 2015).

\section{Affymetrix DNA microarray and data analysis}

AC treated as described above were used to prepare RNA; three biological replicates were done for each condition. Biotinylated probe was prepared according to manufacturer's instructions (Affymetrix). Probes were hybridized to $X$. laevis genome arrays 2.0 (Affymetrix). The hybridized arrays were washed by the GeneChip Fluidics station 450, and scanned with the GeneChip Scanner 3000 (Affymetrix). Gene expression profiles were analyzed by the Partek Genomics Suite software (Partek). The microarray data set was submitted to the NCBI GEO database and obtained accession number GSE72391.

\section{Acknowledgement}

This work was supported by grants from the Research Grants Council of Hong Kong N_CUHK413/12, CUHK24100414, and Lo Kwee-Seong Biomedical Research Fund (SBS-specific) to H. Z., and by the Intramural Research Program of the National Institute of Child Health and Human Development, NIH. We thank colleagues in our laboratories for helpful discussion on this project. 


\section{References}

ALI, Y.M., HAYAT, A., SAEED, B.M., HALEEM, K.S., ALSHAMRANI, S., KENAWY, H.I., FERREIRA, V.P., SAGGU, G., BUCHBERGER, A., LACHMANN, P.J. et al., (2014). Low-dose recombinant properdin provides substantial protection against Streptococcus pneumoniae and Neisseria meningitidis infection. Proc Natl Acad Sci USA 111: 5301-5306.

BAE, C.J., PARK, B.Y., LEE, Y.H., TOBIAS, J.W., HONG, C.S. and SAINT-JEANNET, J.P. (2014). Identification of Pax3 and Zic1 targets in the developing neural crest. Dev Biol 386: 473-483.

BALASCO, N., PIRONE, L., SMALDONE, G., DI GAETANO, S., ESPOSITO, L., PEDONE, E.M. and VITAGLIANO, L. (2014). Molecular recognition of Cullin3 by KCTDs: insights from experimental and computational investigations. Biochim Biophys Acta 1844: 1289-1298.

BAYON, Y., TRINIDAD, A.G., DE LA PUERTA, M.L., DEL CARMEN RODRIGUEZ, M., BOGETZ, J., ROJAS, A., DE PEREDA, J.M., RAHMOUNI, S., WILLIAMS, S., MATSUZAWA, S. et al., (2008). KCTD5, a putative substrate adaptor for cullin3 ubiquitin ligases. FEBS J 275: 3900-3910.

BREWER, S., FENG, W., HUANG, J., SULLIVAN, S. and WILLIAMS, T. (2004). Wnt1-Cre-mediated deletion of AP-2alpha causes multiple neural crest-related defects. Dev Biol 267: 135-152.

CANETTIERI, G., DI MARCOTULLIO, L., GRECO, A., CONI, S., ANTONUCCI, L., INFANTE, P., PIETROSANTI, L., DE SMAELE, E., FERRETTI, E., MIELE, E. etal., (2010). Histone deacetylase and Cullin3-REN(KCTD11) ubiquitin ligase interplay regulates Hedgehog signalling through Gli acetylation. Nat Cell Biol 12: 132-142.

CHEN, Y., YANG, Z., MENG, M., ZHAO, Y., DONG, N., YAN, H., LIU, L., DING, M., PENG, H.B. and SHAO, F. (2009). Cullin mediates degradation of RhoA through evolutionarily conserved BTB adaptors to control actin cytoskeleton structure and cell movement. Mol Cell 35: 841-855.

CORREALE, S., PIRONE, L., DI MARCOTULLIO, L., DE SMAELE, E., GRECO, A., MAZZA, D., MORETTI, M., ALTERIO, V., VITAGLIANO, L., DI GAETANO, S. et al., (2011). Molecular organization of the cullin E3 ligase adaptor KCTD11. Biochimie 93: 715-724.

DE CROZE, N., MACZKOWIAK, F. and MONSORO-BURQ, A.H. (2011). Reiterative AP2a activity controls sequential steps in the neural crest gene regulatory network. Proc Natl Acad Sci USA 108: 155-160.

DING, X., LUO, C., ZHOU, J., ZHONG, Y., HU, X., ZHOU, F., REN, K., GAN, L., HE, A., ZHU, J. et al., (2009). The interaction of KCTD1 with transcription factor AP2alpha inhibits its transactivation. J Cell Biochem 106: 285-295.

DUTTA, S. and DAWID, I.B. (2010). Kctd15 inhibits neural crest formation by attenuating Wnt/beta-catenin signaling output. Development 137: 3013-3018.

ECKERT, D., BUHL, S., WEBER, S., JAGER, R. and SCHORLE, H. (2005). The AP-2 family of transcription factors. Genome Biol 6: 246.

GAMSE, J.T., KUAN, Y.S., MACURAK, M., BROSAMLE, C., THISSE, B., THISSE, C. and HALPERN, M.E. (2005). Directional asymmetry of the zebrafish epithalamus guides dorsoventral innervation of the midbrain target. Development 132 : 4869-4881.

GARNETT, A.T., SQUARE, T.A. and MEDEIROS, D.M. (2012). BMP, Wnt and FGF signals are integrated through evolutionarily conserved enhancers to achieve robust expression of Pax3 and Zic genes at the zebrafish neural plate border. Development 139: 4220-4231.

GROVES, A.K. and LABONNE, C. (2014). Setting appropriate boundaries: fate, patterning and competence at the neural plate border. Dev Biol 389: 2-12.

GUTIERREZ-AGUILAR, R., KIM, D.H., WOODS, S.C. and SEELEY, R.J. (2012). Expression of new loci associated with obesity in diet-induced obese rats: from genetics to physiology. Obesity (Silver Spring) 20: 306-312.

HALDIN, C.E. and LABONNE, C. (2010). SoxE factors as multifunctional neural crest regulatory factors. Int J Biochem Cell Biol 42: 441-444.

HILGER-EVERSHEIM, K., MOSER, M., SCHORLE, H. and BUETTNER, R. (2000). Regulatory roles of AP-2 transcription factors in vertebrate development, apoptosis and cell-cycle control. Gene 260: 1-12.

HOFFMAN, T.L., JAVIER, A.L., CAMPEAU, S.A., KNIGHT, R.D. and SCHILLING, T.F. (2007). Tfap2 transcription factors in zebrafish neural crest development and ectodermal evolution. J Exp Zool B Mol Dev Evol 308: 679-691.

HONG, C.S. and SAINT-JEANNET, J.P. (2007). The activity of Pax3 and Zic1 regulates three distinct cell fates at the neural plate border. Mol Biol Cell 18: 2192-2202.
HU, X., GAN, S., XIE, G., LI, L., CHEN, C., DING, X., HAN, M., XIANG, S. and ZHANG, J. (2014). KCTD10 is critical for heart and blood vessel development of zebrafish. Acta Biochim Biophys Sin (Shanghai) 46: 377-386.

IKEDA, K., MAEGAWA, H., UGI, S., TAO, Y., NISHIO, Y., TSUKADA, S., MAEDA, S. and KASHIWAGI, A. (2006). Transcription factor activating enhancer-binding protein-2beta. A negative regulator of adiponectin gene expression. $J$ Biol Chem 281: 31245-31253

IKEYA, M., LEE, S.M., JOHNSON, J.E., MCMAHON, A.P. and TAKADA, S. (1997) Wnt signalling required for expansion of neural crest and CNS progenitors. Nature 389: 966-970.

JIANG, M.S., TANG, Q.Q., MCLENITHAN, J., GEIMAN, D., SHILLINGLAW, W. HENZEL, W.J. and LANE, M.D. (1998). Derepression of the C/EBPalpha gene during adipogenesis: identification of AP-2alpha as a repressor. Proc Natl Acad Sci USA 95: 3467-3471

KNIGHT, R.D., JAVIDAN, Y., ZHANG, T., NELSON, S. and SCHILLING, T.F. (2005). AP2-dependent signals from the ectoderm regulate craniofacial development in the zebrafish embryo. Development 132: 3127-3138.

KOZHEMYAKINA, E., LASSAR, A.B. and ZELZER, E. (2015). A pathway to bone: signaling molecules and transcription factors involved in chondrocyte development and maturation. Development 142: 817-831.

LEON-MIMILA, P., VILLAMIL-RAMIREZ, H., VILLALOBOS-COMPARAN, M. VILLARREAL-MOLINA, T., ROMERO-HIDALGO, S., LOPEZ-CONTRERAS, B., GUTIERREZ-VIDAL, R., VEGA-BADILLO, J., JACOBO-ALBAVERA, L., POSADAS-ROMEROS, C. et al., (2013). Contribution of common genetic variants to obesity and obesity-related traits in mexican children and adults. PLOS One 8: e70640.

LI, W. and CORNELL, R.A. (2007). Redundant activities of Tfap2a and Tfap2c are required for neural crest induction and development of other non-neural ectoderm derivatives in zebrafish embryos. Dev Biol 304: 338-354.

LI, X., CHEN, C., WANG, F., HUANG, W., LIANG, Z., XIAO, Y., WEI, K., WAN, Z., HU, X., XIANG, S. et al., (2014). KCTD1 suppresses canonical Wnt signaling pathway by enhancing beta-catenin degradation. PLoS One 9: e94343.

LIU, Z., XIANG, Y. and SUN, G. (2013). The KCTD family of proteins: structure, function, disease relevance. Cell Biosci 3: 45.

LONG, F. and ORNITZ, D.M. (2013). Development of the endochondral skeleton. Cold Spring Harb Perspect Biol 5: a008334.

LUO, T., LEE, Y.H., SAINT-JEANNET, J.P. and SARGENT, T.D. (2003). Induction of neural crest in Xenopus by transcription factor AP2alpha. Proc Natl Acad Sci USA 100: 532-537.

LUO, T., ZHANG, Y., KHADKA, D., RANGARAJAN, J., CHO, K.W. and SARGENT, T.D. (2005). Regulatory targets for transcription factor AP2 in Xenopus embryos. Dev Growth Differ 47: 403-413.

MARNEROS, A.G., BECK, A.E., TURNER, E.H., MCMILLIN, M.J., EDWARDS, M.J., FIELD, M., DE MACENA SOBREIRA, N.L., PEREZ, A.B., FORTES, J.A., LAMPE, A.K. et al., (2013). Mutations in KCTD1 cause scalp-ear-nipple syndrome. Am J Hum Genet 92: 621-626.

MCLIN, V.A., HU, C.H., SHAH, R. and JAMRICH, M. (2008). Expression of complement components coincides with early patterning and organogenesis in Xenopus laevis. Int J Dev Biol 52: 1123-1133.

MEI, H., CHEN, W., JIANG, F., HE, J., SRINIVASAN, S., SMITH, E.N., SCHORK, N., MURRAY, S. and BERENSON, G.S. (2012). Longitudinal replication studies of GWAS risk SNPs influencing body mass index over the course of childhood and adulthood. PLoS One 7: e31470.

MENG, X., KONDO, M., MORINO, K., FUKE, T., OBATA, T., YOSHIZAKI, T., UGI, S. NISHIO, Y., MAEDA, S., ARAKI, E. et al., (2010). Transcription factor AP-2beta: a negative regulator of IRS-1 gene expression. Biochem Biophys Res Commun 392: 526-532.

MILET, C., MACZKOWIAK, F., ROCHE, D.D. and MONSORO-BURQ, A.H. (2013) Pax3 and Zic1 drive induction and differentiation of multipotent, migratory, and functional neural crest in Xenopus embryos. Proc Natl Acad Sci USA 110: 5528-5533.

MONSORO-BURQ, A.H., WANG, E. and HARLAND, R. (2005). Msx1 and Pax3 cooperate to mediate FGF8 and WNT signals during Xenopus neural crest induction. Dev Cell 8: 167-178.

NIEUWKOOP, P.D. and FABER, J. (1967). Normal table of Xenopus laevis (Daudin) Garland publishing inc., New York.

ORSO, F., PENNA, E., CIMINO, D., ASTANINA, E., MAIONE, F., VALDEMBRI, D. 
GIRAUDO, E., SERINI, G., SISMONDI, P., DE BORTOLI, M. et al., (2008). AP2alpha and AP-2gamma regulate tumor progression via specific genetic programs. FASEB J 22: 2702-2714.

PEREZ-TORRADO, R., YAMADA, D. and DEFOSSEZ, P.A. (2006). Born to bind: the BTB protein-protein interaction domain. Bioessays 28: 1194-1202.

PLOUHINEC, J.L., ROCHE, D.D., PEGORARO, C., FIGUEIREDO, A.L., MACZKOWIAK, F., BRUNET, L.J., MILET, C., VERT, J.P., POLLET, N., HARLAND, R.M. et al., (2014). Pax3 and Zic1 trigger the early neural crest gene regulatory network by the direct activation of multiple key neural crest specifiers. Dev Biol 386: $461-472$

RAJALU, M., FRITZIUS, T., ADELFINGER, L., JACQUIER, V., BESSEYRIAS, V., GASSMANN, M. and BETTLER, B. (2015). Pharmacological characterization of GABAB receptor subtypes assembled with auxiliary KCTD subunits. Neuropharmacology 88: 145-154.

SAINT-JEANNET, J.P., HE, X., VARMUS, H.E. and DAWID, I.B. (1997). Regulation of dorsal fate in the neuraxis by Wnt-1 and Wnt-3a. Proc Natl Acad Sci USA 94: 13713-13718

SATO, T., SASAI, N. and SASAI, Y. (2005). Neural crest determination by co-activation of Pax3 and Zic1 genes in Xenopus ectoderm. Development 132: 2355-2363.

SCHORLE, H., MEIER, P., BUCHERT, M., JAENISCH, R. and MITCHELL, P.J. (1996). Transcription factor AP-2 essential for cranial closure and craniofacial development. Nature 381: 235-238.

SHI, W., XU, G., WANG, C., SPERBER, S.M., CHEN, Y., ZHOU, Q., DENG, Y. and ZHAO, H. (2015). Heat shock 70-kDa protein 5 (Hspa5) is essential for pronephros formation by mediating retinoic acid signaling. J Biol Chem 290: 577-589.

SIMOES-COSTA, M. and BRONNER, M.E. (2015). Establishing neural crest identity: a gene regulatory recipe. Development 142: 242-257.

SKOBLOV, M., MARAKHONOV, A., MARAKASOVA, E., GUSKOVA, A., CHANDHOKE, V., BIRERDINC, A. and BARANOVA, A. (2013). Protein partners of KCTD proteins provide insights about their functional roles in cell differentiation and vertebrate development. Bioessays 35: 586-596.

SMALDONE, G., PIRONE, L., BALASCO, N., DI GAETANO, S., PEDONE, E.M. and VITAGLIANO, L. (2015). Cullin 3 Recognition Is Not a Universal Property among KCTD Proteins. PLoS One 10: e0126808.

STOGIOS, P.J., DOWNS, G.S., JAUHAL, J.J., NANDRA, S.K. and PRIVE, G.G. (2005). Sequence and structural analysis of BTB domain proteins. Genome Biol 6: R82.
TAO, Y., MAEGAWA, H., UGI, S., IKEDA, K., NAGAI, Y., EGAWA, K., NAKAMURA, T., TSUKADA, S., NISHIO, Y., MAEDA, S. et al., (2006). The transcription factor AP-2beta causes cell enlargement and insulin resistance in 3T3-L1 adipocytes. Endocrinology 147: 1685-1696.

TONG, X., ZU, Y., LI, Z., LI, W., YING, L., YANG, J., WANG, X., HE, S., LIU, D., ZHU, Z. et al., (2014). Kctd10 regulates heart morphogenesis by repressing the transcriptional activity of Tbx5a in zebrafish. Nat Commun 5: 3153.

WANG, C., KAM, R.K., SHI, W., XIA, Y., CHEN, X., CAO, Y., SUN, J., DU, Y., LU, G., CHEN, Z. et al., (2015). The Proto-oncogene Transcription Factor Ets1 Regulates Neural Crest Development through Histone Deacetylase 1 to Mediate Output of Bone Morphogenetic Protein Signaling. J Biol Chem 290: 21925-21938.

WANG, C., LIU, Y., CHAN, W.Y., CHAN, S.O., GRUNZ, H. and ZHAO, H. (2011) Characterization of three synuclein genes in Xenopus laevis. Dev. Dynam. 240: 2028-2033.

WANG, Y., ZHENG, Y., LUO, F., FAN, X., CHEN, J., ZHANG, C. and HUI, R. (2009). KCTD10 interacts with proliferating cell nuclear antigen and its down-regulation could inhibit cell proliferation. J Cell Biochem 106: 409-413.

WENKE, A.K. and BOSSERHOFF, A.K. (2010). Roles of AP-2 transcription factors in the regulation of cartilage and skeletal development. FEBS J 277: 894-902.

WILLER, C.J.SPELIOTES, E.K.LOOS, R.J.LI, S.LINDGREN, C.M.HEID, I.M.BERNDT, S.I.ELLIOTT, A.L.JACKSON, A.U.LAMINA, C. etal., (2009). Six new lociassociated with body mass index highlight a neuronal influence on body weight regulation. Nat Genet 41: 25-34

WILLIAMS, M.J., ALMEN, M.S., FREDRIKSSON, R. and SCHIOTH, H.B. (2012) What model organisms and interactomics can reveal about the genetics of human obesity. Cell Mol Life Sci. 13. 69: 3819-3834.

ZARELLI, V.E. and DAWID, I.B. (2013). Inhibition of neural crest formation by Kctd15 involves regulation of transcription factor AP-2. Proc Natl Acad Sci USA 110: 2870-2875.

ZHANG, Z.C., LIU, Y., LI, S.F., GUO, L., ZHAO, Y., QIAN, S.W., WEN, B., TANG, Q.Q. and $\mathrm{LI}, \mathrm{X}$. (2014). Suv39h1 mediates AP-2alpha-dependent inhibition of $\mathrm{C} /$ EBPalpha expression during adipogenesis. Mol Cell Biol 34: 2330-2338.

ZHAO, H., TANEGASHIMA, K., RO, H. and DAWID, I.B. (2008). Lrig3 regulates neural crest formation in Xenopus by modulating Fgf and Wnt signaling pathways. Development 135: 1283-1293. 


\section{Further Related Reading, published previously in the Int. J. Dev. Biol.}

pdzrn3 is required for pronephros morphogenesis in Xenopus laevis

Silvia Marracci, Alberto Vangelisti, Vittoria Raffa, Massimiliano Andreazzoli and Luciana Dente

Int. J. Dev. Biol. (2016) 60: 57-63

http://dx.doi.org/10.1387/ijdb.150381ld

Differential expression of arid5b isoforms in Xenopus laevis pronephros

Ronan Le Bouffant, Anne-Claire Cunin, Isabelle Buisson, Jérôme Cartry, Jean-François Riou and Muriel Umbhauer

Int. J. Dev. Biol. (2014) 58: 363-368

http://dx.doi.org/10.1387/ijdb.140029mu

\section{Expression pattern of zcchc24 during early Xenopus development}

Marta Vitorino, Elizabeth Correia, Ana-Rita Serralheiro, Ana-Catarina De-Jesus, José M. Inácio and José A. Belo

Int. J. Dev. Biol. (2014) 58: 45-50

http://dx.doi.org/10.1387/ijdb.130261jb

Kidins220/ARMS is dynamically expressed during Xenopus laevis development

Silvia Marracci, Marianna Giannini, Marianna Vitiello, Massimiliano Andreazzoli and Luciana Dente

Int. J. Dev. Biol. (2013) 57: 787-792

http://dx.doi.org/10.1387/ijdb.130080sm

The Wnt signaling mediator tcf1 is required for expression of foxd3 during Xenopus gastrulation

Sylvie Janssens, Olaf Van Den Broek, lan R. Davenport, Robbert C. Akkers, Fei Liu, Gert Jan C. Veenstra, Stefan Hoppler, Kris Vleminckx and Olivier Destrée

Int. J. Dev. Biol. 57: 49 - 54 (2013) doi: 10.1387/ijdb.120191kv

Expression of Sox family genes in early lamprey development

Benjamin R. Uy, Marcos Simoes-Costa, Tatjana Sauka-Spengler and Marianne E. Bronner Int. J. Dev. Biol. 56: 377 - 383 (2012) doi: 10.1387/ijdb.113416bu

Cloning and developmental expression of zebrafish pdzrn3

Luciana Dente, Gaia Gestri, Michael Tsang, Tetsuhiro Kudoh, Stephen W. Wilson, Igor B. Dawid and Massimiliano Andreazzoli

Int. J. Dev. Biol. (2011) 55: 989-993

http://dx.doi.org/10.1387/ijdb.113437ld

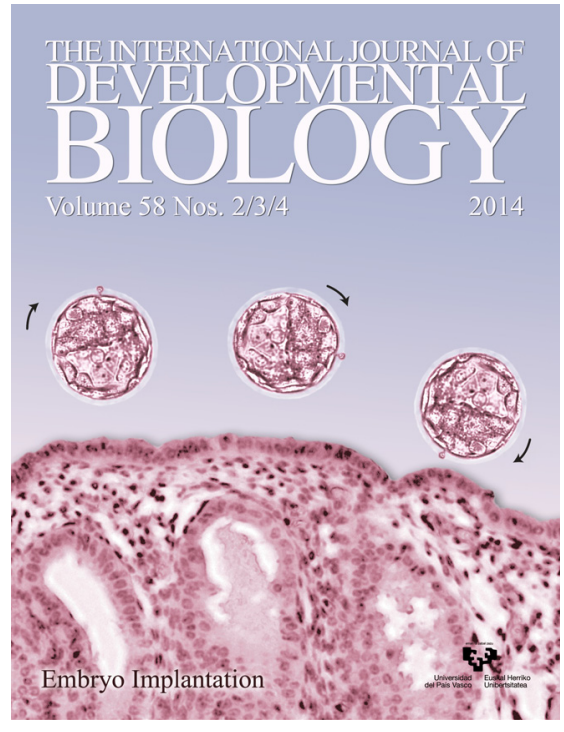

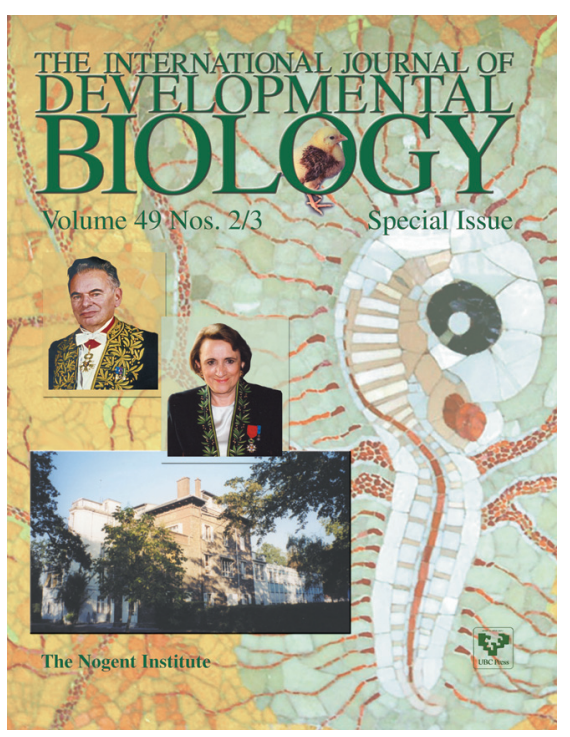

5 yr ISI Impact Factor $(2013)=2.879$
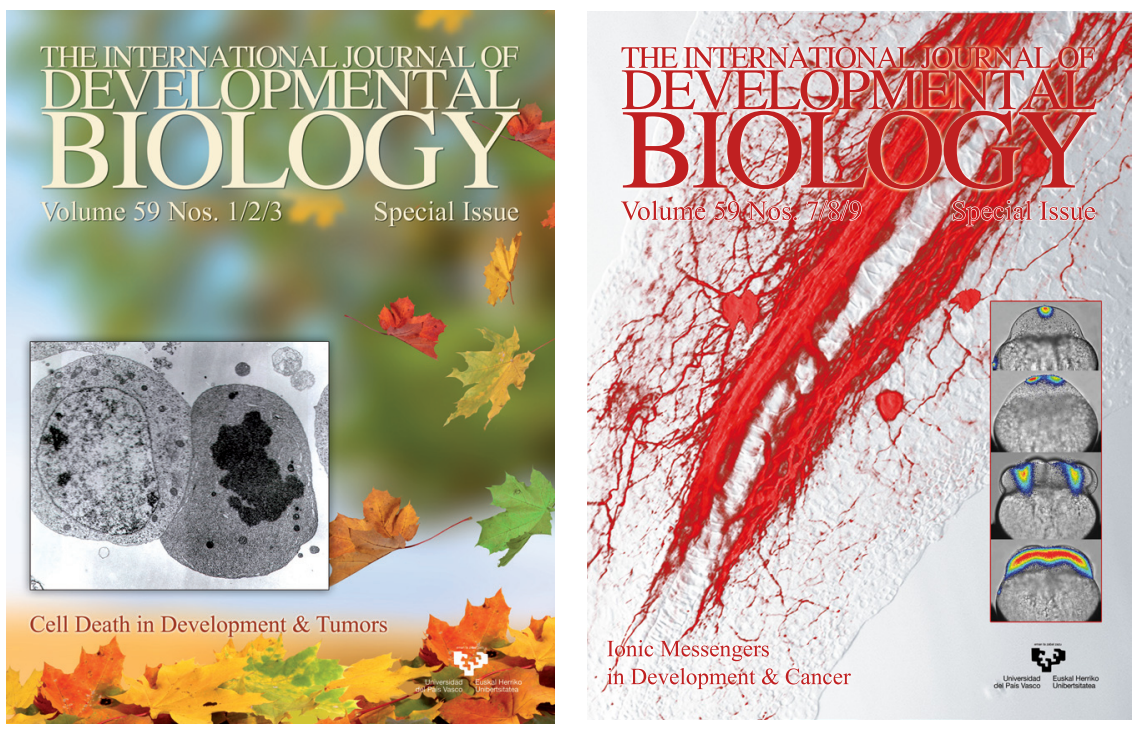